\title{
Brief review: Angiotensin converting enzyme inhibitors and angioedema: anesthetic implications
} [Revue sommaire sur les implications anesthésiques de l'xdème de Quincke et des inhibiteurs de l'enzyme de conversion de l'angiotensine]

Putul Sarkar MB BS, Grainne Nicholson MB BS, George Hall PhD

Purpose: Angiotensin converting enzyme inhibitors (ACEls) are a group of drugs used to treat hypertension and heart failure, with additional benefits, such as cardiovascular and renal protection, in patients with diabetes. However, angioedema as a complication of ACEI therapy is under-recognized. As there are important implications for anesthesiologists and emergency medicine physicians, a review was undertaken to document the scope of the problem of ACEl-induced angioedema..

Methods: A review of the published literature (identified by searching Medline, EMBASE and CINAHL) was undertaken, addressing the clinical uses of ACEls and the incidence, risk factors, pathophysiology, clinical presentation and management of angioedema associated with the use of these drugs.

Principal findings: The incidence of ACEI related angioedema has increased from $0.1-0.2 \%$ to $1 \%$ over the last decade. Patients who are receiving ACEls are predisposed to developing angioedema which may be triggered by trauma, airway instrumentation, infection, and irritant fumes, particularly in those who are at increased risk. Cases of acute facial and airway oedema, due to ACEI drug administration, may be misdiagnosed as an anaphylactic reaction, and the association with ACEls may be ignored. Some cases of intraoperative and postoperative airway edema may be precipitated by airway instrumentation in patients receiving ACEI drugs. The severity of airway compromise ranges from mild facial edema to severe laryngeal or subglottic edema which may prove life-threatening.

Conclusion: In view of the widespread clinical indications and ever-increasing use of ACEI drugs, the potentially life-threatening adverse reaction of $\mathrm{ACEl}$-associated angioedema, and its treatment, must be recognized by anesthesiologists and all clinicians involved in airway management.
Objectif : Les inhibiteurs de l'enzyme de conversion de l'angiotensine (IECA) sont utilisés contre l'hypertension et l'insuffisance cardiaque et aussi pour la protection cardiovasculaire et rénale, chez les patients diabétiques. L'œdème de Quincke est toutefois peu connu comme complication de l'usage des IECA. Cette situation ayant des répercussions sur le travail des anesthésiologistes et des urgentistes, une revue a été réalisée pour montrer l'étendue du problème de l'œdème de Quincke induit par l'IECA.

Méthode: Une revue des articles publiés (découverts dans Medline, EMBASE et CINAHL) a été faite en abordant les usages cliniques des IECA, l'incidence, les facteurs de risque, la physiopathologie, la présentation et le traitement cliniques de l'œdème de Quincke associés à ces médicaments.

Constatations principales: L'incidence d'œdème de Quincke relié aux IECA est passée $0, I-0,2 \%$ à I \% pendant la dernière décennie. Les patients qui prennent des IECA sont prédisposés à l'œdème de Quincke qui peut être déclenché par un traumatisme, une exploration instrumentale, une infection et des émanations irritantes, surtout chez ceux qui sont à haut risque. L'œdème aigu du visage et des voies aériennes peut être diagnostiqué à tort comme une réaction anaphylactique et l'association avec les IECA restée inconnue. L'œdème peropératoire et postopératoire des voies aériennes peut dépendre de l'utilisation d'instruments dans les voies aériennes. La sévérité de l'atteinte peut être un léger œdème facial jusqu'à un œdème laryngé ou sous-glottique important et même très grave.

Conclusion: Dans l'optique des indications cliniques largement répandues, et en augmentation constante, de l'usage des IECA, la réaction indésirable et possiblement grave qu'est l'œdème de Quincke, et son traitement, doivent être connus des anesthésiologistes et de tous les cliniciens concernés par le contrôle des voies aériennes.

From the Department of Anaesthesia and Intensive Care Medicine, St George's Hospital Medical School, London, UK. Address correspondence to: Dr. Grainne Nicholson, Dept. of Anaesthesia, St George's Hospital Medical School, London SW17 0RE,

UK. Phone: 0044208725 3629; Fax: 0044208725 0256; E-mail: gnichols@sgul.ac.uk Accepted for publication February 17, 2006.

Revision accepted May 29, 2006.

Competing interests: None declared. 


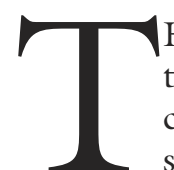

HE first commercially available oral angiotensin converting enzyme inhibitor (ACEI), captopril, was introduced in the 1980s and since then, the number of ACEIs and their applications for the treatment of hypertension and heart failure has increased considerably. These drugs, are not, however, without important side effects. Angioedema, characterised by an acute onset nonpitting edema of the skin, mucosa and $s c$ tissues, is a well-documented side effect of ACEIs, and it has been included in Food and Drug Administration-approved package inserts since the mid -1980s as a complication of ACEI therapy. However, the problem of ACEIinduced angioedema remains under-recognized ${ }^{1-6}$ despite the fact that the association between ACEI and angioedema is well documented in the literature, and it is now considered to be one of the commonest causes of non-hereditary angioedema. ${ }^{7,8}$

The problem of ACEI-induced angioedema is particularly relevant to anesthesiologists and emergency medicine physicians, as angioedema can cause rapid and progressive airway compromise which may be life-threatening. A significant number of patients now present to the emergency department with this complication. $.^{9}, 10$ Life-threatening intraoperative and postoperative angioedema related to ACEI drugs has also been reported, ${ }^{11-13}$ In view of the number of clinical indications and ever-increasing use of ACEI drugs, this potentially life-threatening adverse reaction ${ }^{14-20}$ needs to be highlighted.

\section{Clinical indications for ACEIs}

Angiotension converting enzyme inhibitors are used widely in the treatment of hypertension, heart failure, myocardial infarction, renal failure, and diabetic nephropathy. Over the last several years, the use of ACEIs has increased enormously, and it is currently estimated that $>40$ million people worldwide are receiving therapy with ACEIs, which could lead to a greater prevalence of angioedema. ${ }^{21}$

A strong correlation exists between circulating angiotensin II concentrations and hypertension. ${ }^{22}$ Angiotension converting enzyme inhibitors are recommended for the treatment of hypertension, especially in the presence of left ventricular dysfunction and congestive heart failure ${ }^{23-27}$ as well as chronic renal disease. ${ }^{28}$ The central role of long-acting ACEIs for cardiovascular protection has been clearly established and this class of drugs is now considered as routine therapy for secondary prevention of cardiovascular disease, together with aspirin, $\beta$-adrenergic blocking drugs, and statins. ${ }^{29-31}$

According to the American Heart Association, the prevalence of heart failure in the United States is esti- mated to be $2.2 \%$. Current recommendations by the American College of Cardiology and the American Heart Association for treating chronic heart failure encourage the use of ACEIs in all patients with left ventricular dysfunction, unless the patient has a specific contraindication or is intolerant to their use. ${ }^{31,32}$ It has been recommended that patients with congestive heart failure (CHF) who have been stabilized on diuretics should be considered for additional ACEI therapy, unless there are specific contraindications (such as aortic stenosis). ${ }^{32}$ The problem of CHF will increase the so-called "heart failure epidemic" 33 because of the impact of treatment (for example thrombolysis) and an aging population. It is anticipated that an increasing number of patients will be prescribed ACEIs in the future.

In addition to their antihypertensive and cardiovascular protective effects, ACE inhibitors may have renal-protective properties. ${ }^{34}$ Although concerns have been expressed about their possible harmful effects in patients with renal disease, ACE inhibition is recommended even in these patients, if the acute rise in serum creatinine with ACE inhibition does not exceed $30 \%$, and stabilizes within two months of the therapy ${ }^{35}$ in patients are not taking non-steroidal antiinflammatory drugs. ${ }^{36}$ Angiotensin converting enzyme inhibitors are associated with renal protection in both diabetic ${ }^{37-44}$ and non-diabetic nephropathies, ${ }^{45-47}$ independently of their antihypertensive effects.

Many individuals with arterial hypertension or CHF are insulin-resistant and at a higher risk of developing type II diabetes mellitus. A meta-analysis of randomized controlled trials has shown that angiotensin inhibition consistently and significantly reduces the incidence of type II diabetes in individuals with arterial hypertension or with $\mathrm{CHF}^{48}$ and can help prevent the progression to nephropathy. This antiproteinuric effect is independent of changes in blood pressure. ${ }^{49}$ In patients with type I diabetes, ACEIs have been shown to prevent diabetic nephropathy. ${ }^{50}$

Other important beneficial actions of ACEIs may include an effect on the fibrinolytic balance decreasing angiotensin II, which is prothrombotic, and increasing bradykinin, which is antithrombotic ${ }^{51}$ and increasing adiponectin levels and insulin sensitivity. ${ }^{52-56}$

\section{Role of the renin-angiotensin system}

Angiotensinogen is a glycoprotein synthesized in the liver. ${ }^{57}$ Renin, a protease enzyme, secreted by the juxtaglomerular apparatus of the nephron, cleaves angiotensin I ( $10 \mathrm{aa}$ ) from angiotensinogen. Angiotensin I is converted to angiotensin II by a converting enzyme. This enzyme has a plasma half life of 15-60 sec and 


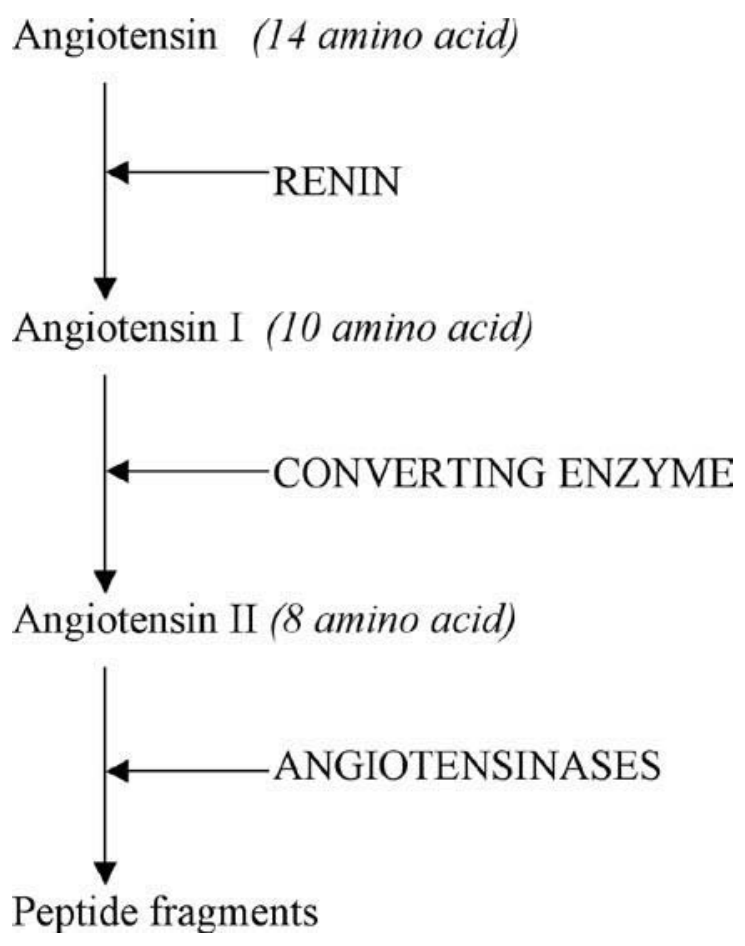

FIGURE Chemistry of the renin-angiotensin system.

is cleared rapidly from the circulation by a variety of enzymes known collectively as angiotensinases. Angiotensin II exerts important actions at several sites including vascular smooth muscle, the adrenal cortex, kidney and brain. It plays a key role in fluid and electrolyte balance, and maintenance of arterial blood pressure. Angiotensin II is a highly potent pressor agent (40 times more potent on an equimolar basis than norepinephrine), with a rapid onset and sustained effect. In addition, it stimulates autonomic ganglia, increases release of epinephrine and norepinephrine, and reduces norepinephrine reuptake. The pressor response to angiotensin II is not accompanied by a reflex bradycardia because it acts centrally to reset the baroceptor reflex to a higher pressure. Other central effects include stimulation of thirst, and increased secretion of vasopressin and adrenocorticotrophic hormone. Angiotensin II acts directly on the zona glomerulosa of the adrenal cortex to stimulate aldosterone biosynthesis and at higher concentrations, it also stimulates glucocorticoid biosynthesis. It causes renal vasoconstriction, increases proximal tubular sodium reabsorbtion, and inhibits the secretion of renin. Angiotensin II is mitogenic for vascular and cardiac muscle cells and may contribute to the development of cardiac hypertrophy. The growth effects of angiotensin II also play a critical role in the development of atherosclerosis and mediate vessel wall changes. Angiotensin II receptors are widely distributed and located on the plasma membranes of target cells. Most of the direct actions of angiotensin II are mediated by the $\mathrm{AT}_{1}$ receptor, a $\mathrm{G}$ protein-coupled receptor.

Converting enzyme inhibitors inhibit the conversion of angiotensin I to angiotensin II and have a number of clinical roles. They decrease systemic vascular resistance without increasing heart rate, and promote natriuresis. Converting enzyme inhibitors are used in the treatment of hypertension, and they decrease morbidity and mortality in heart failure, improve left ventricular function after myocardial infarction, and delay the progression of diabetic nephropathy. Angiotensin II antagonists are specific competitive antagonists at $\mathrm{AT}_{1}$ receptors.

\section{Angioedema: types and causes}

Angioedema, which may be hereditary or non-hereditary, is characterized by an acute-onset non-pitting edema of the skin, mucosa and sc tissues. Hereditary angioedema is a rare autosomal dominant disorder which is characterized by recurrent attacks of angioedema resulting from a deficiency of $\mathrm{Cl}$ esterase inhibitor enzyme (Cl-INH). ${ }^{6}$ The complement system consists of about 20 proteins, most of which circulate as inactive precursors. Activation of the system via one of two pathways - classical or alternative, results in opsonization, lysis, chemotaxis, histamine release and immune complex clearance. The enzymes are identified by the numbers $\mathrm{Cl}-\mathrm{C}$. The first component of the classical complement pathway is $\mathrm{Cl}$, which is composed of three subunits $\mathrm{Clq}, \mathrm{Clr}$ and $\mathrm{Cls} .{ }^{58} \mathrm{Cl}$ binds to immunoglobulins which have bound antigen, and this triggers the sequence of events which activate other components of the cascade. Control proteins, including $\mathrm{Cl}$ esterase inhibitor enzyme (Cl-INH), normally limit the amount of complement activation, but in the presence of hereditary or acquired Cl-INH deficiency the complement pathway is activated, leading to the generation of biologically active substances such as bradykinin. These result in increased vascular permeability and edema of airway, trunk, limbs and gastrointestinal tract.

The causes of non-hereditary angioedema are variable and include acquired $\mathrm{Cl}$ esterase inhibitor deficiency, which is a result of an auto-antibody to Cl-INH, or generation of anti-idiotypic antibody to monoclonal immunoglobulins which occur in various B cell lymphoproliferative diseases and other 
malignancies. ${ }^{59}$ Non-hereditary angioedema may also be idiopathic, or due to an allergic reaction to food, various inhalants, or immune complex diseases. ${ }^{58}$ Angiotensin converting enzyme inhibitors now present one of the most common causes of non-hereditary angioedema, accounting for $25-39 \%$ of cases. ${ }^{7,8}$ Angioedema may be caused by other drugs as well, particularly aspirin and non-steroidal anti-inflammatory medications, radio-contrast media, angiotensin II receptor antagonists, and certain antibiotics. ${ }^{60}$ Several cases of severe angioedema have been reported following treatment with fibrinolytic agents, ${ }^{61,62}$ and a possible association with the use of estrogens, other antihypertensive drugs, psychotropics, and non-steroidal anti-inflammatory drugs has been suggested. ${ }^{63}$ However there remains a relative paucity of knowledge regarding which specific drugs can precipitate angioedema, reflecting in part, the sporadic and random reporting of adverse events.

The prevalence of ACEI-related angioedema is frequently underestimated, particularly when its presentation is delayed following long-term therapy. Although many large studies report an incidence of angioedema in the range of $0.1-0.2 \%$ in patients treated with ACEIs, ${ }^{1,64}$ recent literature suggests a higher incidence in excess of $>1 \%$ of treated patients. ${ }^{2,3}$ The recent OCTAVE study, ${ }^{4,65}$ involving over 25,000 hypertensive patients, found that $0.68 \%$ of patients treated with enalapril developed angioedema. One possible factor to account for the rising incidence of angioedema may be increased use of long-acting ACEI drugs such as enalapril, lisinopril and ramipril, in lieu of the shorter-acting captopril. Reports of angioedema associated with ACEIs submitted to the Swedish Adverse Reactions Advisory Committee and to the World Health Organisation's international drug information system were reviewed. ${ }^{9}$ From 1981 to $1990,1,309$ cases of angioedema associated with ACEIs were registered with the international drug information system; 36 of the 38 reported cases in Sweden between 1981 and 1990 were judged to be related to ACEIs. It is notable that $38 \%$ of patients presenting to a teaching hospital emergency department with angioedema were taking an ACEI. ${ }^{5}$ In a retrospective study conducted over a four-year period, ACEIs were found to be the most common cause of acute angioedema in a tertiary referral teaching hospital in the United States. ${ }^{66}$ Of the 40 patients presenting with angioedema in this study, 15 cases were associated with the use of ACEIs. In a more recent retrospective study, 64\% cases of angioedema were thought to be related to ACEI therapy. ${ }^{6}$ Hence, from a practical point of view, a thorough review must be conducted of all medications to exclude angioedema caused by ACEI treatment.

Although angioedema has been reported with all the ACEI drugs, angioedema associated with a shorter-acting drug such as captopril may be less severe than that associated with long-acting ACEI medications. ${ }^{67}$ Furthermore, it has been suggested that the incidence of angioedema associated with lisinopril is greater than that associated with captopril or enalapril. ${ }^{68}$ In a large recent study, the incidence of angioedema secondary to perindropril was found to be relatively low $(0.4 \%){ }^{69}$

Angioedema has been reported to occur early after initiation of treatment, mostly within the first one to four weeks. However, according to reports dating back to 1990, the onset may be delayed for months and even until up to seven years after initiating treatment. ${ }^{1,15,70,71}$ Analysis of patients presenting with angioedema, reported to the National Drug Commission in Germany, revealed that the number of patients with late onset angioedema is increasing. ${ }^{71}$ Late onset angioedema, secondary to treatment with ACEI therapy, is largely unrecognized because of the absence of a temporal correlation between ACEI therapy and development of angioedema. ${ }^{14,69}$ Occasional episodes of angioedema associated with ACEI therapy may be interspersed with prolonged asymptomatic periods, despite the continued administration of these drugs. These variable temporal relationships between drug administration and adverse events can contribute to a failure to recognize the association, and delay a decision to discontinue ACEIs. ${ }^{72-74}$ Many patients experience multiple episodes of angioedema because even clinicians in emergency departments are not familiar with the association between angioedema and ACEIs. ${ }^{71}$

\section{Pathophysiology and mechanisms}

The pathophysiology of ACEI-induced angioedema has not been fully elucidated. However, it appears to be a biochemically related, rather than an immunologically mediated ${ }^{74}$ phenomenon. Angiotensinconverting enzyme inactivates the potent vasodilator bradykinin and converts angiotensin I to angiotensin II, a potent vasoconstrictor. The action of ACE inhibitors depends mainly on blocking the angiotensin converting enzyme in the renin-angiotensin-aldosterone system. Angiotensin converting enzyme inhibitors produce vasodilation by causing an increase in the level of bradykinin and a decrease in angiotensin II level. The long-term benefit of ACE inhibition in patients with heart failure results from augmentation of bradykinin, and not from the inhibition of angiotensin II production. ${ }^{75}$ It has been suggested that 
bradykinin accumulates in patients who are on ACEIs because of inhibition of the kininase enzyme that is responsible for its metabolism. This may cause vasodilation and tissue edema in susceptible individuals. The angiotensin converting enzyme itself has kinase activity, and inhibition of this enzyme can result in accumulation of tissue mediators. However, at present, there is no conclusive evidence to support this theory. Other mediators such as histamine, substance $\mathrm{P}$, and prostaglandins may also be involved in the pathogenesis of angioedema. ${ }^{14,76}$ The circulating concentration of bradykinin is not altered by ACEI drugs,${ }^{74,77}$ thus, it is local increases in bradykinin which are responsible for vasodilation. This explains the local swelling after ACEI-related angioedema triggered by minor trauma and the lack of generalized edema. Trauma may trigger angioedema by activating the kallikrein-kinin pathway. The $\mathrm{Cl}$ esterase, $\mathrm{C} 4$, and $\mathrm{IgE}$ levels are normal in ACEI-induced angioedema. Approximately half of patients experiencing ACEI-associated angioedema may have an enzyme defect involved in des-Arg9-bradykinin metabolism, leading to its accumulation, and it has been suggested that an enzyme defect rather than a circulating inhibitor could be responsible for the abnormal metabolism of des-Arg9-BK when ACE is inhibited..$^{78}$ An abnormality of endogenous des$\operatorname{Arg}(9)$-BK degradation was found in the plasma of patients with ACEI-associated angioedema, suggesting that its pathogenic mechanism lies in the catabolic site of kinin metabolism..$^{79}$ Although less frequent, the occurrence of angioedema with angiotensin II receptor blockers suggests that bradykinin is not the only mechanism involved in ACEI-induced angioedema. ${ }^{9}$

While Cl-esterase inhibitor levels are usually normal in subjects developing ACEI-dependent angioedema, it has been found that ACEIs caused angioedema in $\mathrm{Cl}$ esterase-inhibitor-deficient patients. ${ }^{74}$ Successful treatment of severe angioedema related to long-term treatment with an ACEI drug, by using $\mathrm{Cl}$ inhibitor concentrate, has been reported. ${ }^{80}$ This suggests that the ACEI may unmask the patient's acquired autoimmune Cl-INH deficiency. ${ }^{81}$ Angiotensin converting enzyme inhibitor-induced angioedema is associated with significantly increased plasma concentrations of $\mathrm{C}$ reactive protein, and it has been suggested that this acute phase reactant may be involved in the pathophysiology of ACEI-induced angioedema. ${ }^{82}$

\section{Risk factors for angioedema}

Angioedema is more common in black individuals of African origin, in patients with a history of hereditary or acquired angioedema, and after cardiac or renal transplantation. ${ }^{3,6,15,83,84}$ It has been suggested that patients with pre-existing narrowing of the airway due to trauma, airway intervention, obesity, or head and neck surgery may be at increased risk. ${ }^{4,14,69,72}$ In a recent study, a history of smoking and ACEI-induced cough were shown to be significant risk factors for developing angioedema. ${ }^{85} \mathrm{~A}$ higher proportion of females are reported to suffer from the condition. ${ }^{86} \mathrm{~A}$ higher incidence in middle-aged and elderly patients may reflect the population for whom ACEIs are generally prescribed. However, currently there is insufficient evidence to suggest a clinical profile that may help to identify patients at risk of ACEI-related angioedema. Angiotensin converting enzyme-related angioedema is a diagnosis of association relying on a high index of suspicion, but must be considered in patients on ACEIs in whom angioedema may be initiated by a second triggering factor such as airway instrumentation, trauma, infection or fumes. ${ }^{15}$

\section{Clinical presentation of ACEI angioedema}

Clinical presentation of ACEI-related angioedema is variable and unpredictable, and it is this variability that makes the diagnosis difficult. ${ }^{74,87}$ Presentation is often delayed; angioedema may start years after commencing treatment and it recurs irregularly. ${ }^{71,87}$ Patients receiving ACEI drugs may have completely symptom-free periods in between attacks of angioedema. The signs and symptoms in most cases are mild, and resolve spontaneously even when the patient continues to take ACEIs. However, attacks of angioedema triggered by ACEI drugs can vary in severity from mild facial edema to potentially fatal airway obstruction. Deaths have resulted from ACEI related angioedema. ${ }^{77,88}$

Areas commonly affected by angioedema include the face, lips, tongue, pharynx, the supraglottic area and, uncommonly, the subglottic area. Angioedema often involves hands and feet, as well as the gastrointestinal mucous membranes and genitalia. ${ }^{85}$ Odynophagia and tongue swelling at the time of presentation have significant implications for diagnostic intervention and admission to the hospital. ${ }^{66}$

Up to $20 \%$ of patients may present with acute onset of dyspnea, dysphagia, dysphonia and stridor, with rapid progression to life-threatening airway obstruction. $1,7,89,90$ Attempts have been made to correlate either the symptoms at presentation or the anatomic site of edema, with subsequent management and outcome. Ishoo et al. reviewed 93 episodes of angioedema over a ten-year period, and proposed a staging system by which airway risk could be predicted from the site of presentation. ${ }^{60}$ In this study, symptoms such as stridor, change in voice, hoarseness and dys- 
pnea were found to be predictive of patients with severe angioedema, and correlated with a need for airway intervention and intensive care unit (ICU) admission. Patients with facial rash, facial edema, lip edema (stage I), and soft palate edema (stage II) were treated as outpatients, and on the hospital ward. Patients with lingual edema (stage III) usually required ICU admission. All patients with laryngeal edema (stage IV) were admitted to the ICU. Airway intervention was performed in $7 \%$ of stage III patients and in $24 \%$ of stage IV cases.

Chiu et al. reviewed 108 patients presenting with angioedema over a five-year period, and proposed a classification system by which airway risk could be predicted from the site of edema at initial presentation. ${ }^{86}$ Patients were classified as:

* Class 1. Isolated facial and oral cavity edema, excluding the floor of the mouth;

* Class 2. Floor of the mouth and/or oropharyngeal edema;

* Class 3. Oropharyngeal edema with glottic and/ or supraglottic involvement.

The authors concluded that airway edema was better tolerated by class 1 patients, while patients graded as class II or III usually required airway intervention.

Visceral angioedema is a rare complication of ACEI and may present as an 'acute abdomen. ${ }^{91,92} \mathrm{~A}$ common presentation is that of a middle-aged female with abdominal pain, emesis, and diarrhea who has recently begun taking an ACEI. Associated signs include leukocytosis, ascites, and edematous small bowel appearing on computed tomography. The diagnosis is elusive, and invasive procedures, including surgery, are frequently pursued. These can be avoided if the physician recognizes the association, and withdraws the medication.

\section{Management of angioedema}

The immediate management of ACEI-related angioedema concerns airway management, and skilled and experienced anesthesiologists, otorhinolaryngologists and emergency medicine physicians should be involved as early as possible in cases of real or impending airway compromise. It has been suggested that fibreoptic nasoendoscopy is an invaluable tool in the assessment of the compromised airway in patients with angioedema. Bentsianov et al. ${ }^{90}$ reported that nine of 14 patients with ACEI-associated angioedema who underwent airway intervention had evidence of laryngeal edema, which is an ominous sign. These authors concluded that when both laryngeal and pharyngeal edema are present, continued observation is critical, as immediate intervention may be warranted, either in the form of endotracheal intubation, or establishment of an emergency surgical airway or tracheostomy. As many as $13-22 \%$ of patients with ACEI-induced angioedema require airway intervention. ${ }^{86,93}$ In a multicentre retrospective review of 108 patients treated for angioedema, ${ }^{86}$ it was found that 14 patients (13\%) received airway intervention, two of whom underwent a cricothyroidotomy after a failed attempt at endotracheal intubation. Eleven (78.6\%) patients who had airway intervention were taking ACEIs. The indication for endotracheal intubation in these patients was massive edema of the tongue and floor of the mouth.

Although in most reported cases of angioedema involving the airway, administration of steroids, antihistamines and nebulized or injected adrenaline have been used as a part of treatment, there is no definite evidence that these drugs are effective in treating ACEI-related angioedema, which is largely a self-limiting disorder once ACEI is discontinued. ${ }^{85,94}$ Stopping the ACEI provides a successful measure in the majority of patients who develop ACEI-related angioedema, ${ }^{94}$ and is considered the next most important step in management, after ensuring patency of the patient's airway. However, failure to recognize the association of ACEI drugs with this condition is common, and not infrequently the offending agent is continued upon discharge from hospital. $, 73,87$ In a retrospective cohort study, review of the medical records of patients taking ACEI who had experienced recurrent angioedema revealed that physicians attributed angioedema to a number of causes unrelated to ACE inhibitor use, even after multiple recurrences. ${ }^{87}$ The lag time between the onset of angioedema and withdrawal of ACEI drug may be long. ${ }^{74}$ It has been shown that amongst ACEI users with one episode of angioedema, the risk of recurrent angioedema is dramatically higher during continued ACEI exposure. ${ }^{17,87}$

Fresh frozen plasma has been used successfully for the treatment of resistant, life-threatening angioedema induced by ACEI. ${ }^{95,96}$ The benefit of fresh frozen plasma in this condition may be due to the effect of kininase II in breaking down accumulated bradykinin. Use of $\mathrm{Cl}$-esterase inhibitor (Cl-INH) for treatment of ACEI induced angioedema has also been described. ${ }^{80}$

Recent data suggest that the majority of patients who develop angioedema from ACEI drugs can tolerate angiotensin-II receptor blockers (ARB)..$^{94,97}$ Angiotensin II receptor antagonists act at the receptor sites and do not affect the angiotensin converting 
enzyme; hence, theoretically, bradykinin levels should remain unaffected. However, sporadic case reports have described angioedema related to angiotensin II receptor blockers, and it is important for clinicians to be aware that ARBs may not be safe alternatives in patients with ACEI related angioedema. ${ }^{94,98-100}$ In $32 \%$ of reported cases of angioedema related to ARB, patients experienced a prior episode of angioedema attributable to ACEI therapy.

\section{Conclusions}

With widespread and increasing use of ACEIs, drugrelated angioedema is becoming a more common medical emergency. Awareness of the association of angioedema with ACEI drugs is critical for anesthesiologists and emergency medicine physicians. The potential role of triggering factors such as recent airway intervention, trauma, or exposure to irritant fumes often goes unrecognized, as many cases of angioedema are still thought to represent an anaphylactic reaction to some other agent. Epinephrine, steroids and antihistamines provide little therapeutic benefit, as this type of angioedema is not an $\mathrm{IgE}$-mediated phenomenon. The airway edema can progress rapidly and may require urgent intervention. Hence, early recognition and timely involvement of an experienced anesthesiologist and otorhinolaryngologist are vital. Physicians must warn patients about this potentially serious side effect when prescribing ACEI medications, and if a patient develops angioedema, ACEI therapy must be discontinued immediately. Clinicians should also bear in mind that switching treatment to ARBs in patients who have experienced angioedema secondary to ACEI may be potentially unsafe. Finally, guidelines on the perioperative use of ACEI drugs may help to reduce morbidity and potential mortality due to airway edema, particularly in patients at high risk of developing this problem.

\section{References}

1 Slater EE, Merril DD, Guess HA, et al. Clinical profile of angioedema with angiotensin-converting enzyme inhibition. JAMA 1988, 260: 967-70.

2 Sweitzer NK. What is an angiotensin converting enzyme inhibitor? Circulation 2003; 108: el6-8.

3 Brown NJ, Ray WA, Snowden M, Griffin MR. Black Americans have an increased rate of angiotensin converting enzyme inhibitor-associated angioedema. Clin Pharmacol Ther 1996; 60: 8-13.

4 Vleeming $W$, van Amsterdam JG, Stricker BH, de Wildt DJ. ACE inhibitor-induced angioedema. Incidence, prevention and management. Drug Saf 1998; 18: 171-88.
5 Gabb GM, Ryan P, Wing LM, Hutchinson KA. Epidemiological study of angioedema and ACE inhibitors. Aust N Z J Med 1996; 26: 777-82.

6 Sondhi D, Lippmann M, Murali G. Airway compromise due to angiotensin-converting enzyme inhibitor-induced angioedema: clinical experience at a large community teaching hospital. Chest 2004; 126 : 400-4.

7 Rai, MR, Amen F, Idrees F. Angiotensin-converting enzyme inhibitor related angioedema and the anaesthetist. Anaesthesia 2004; 59: 283-9.

8 Megerian CA, Arnold JE, Berger M. Angioedema: 5 years' experience, with a review of the disorder's presentation and treatment. Laryngoscope 1992; 102: 256-60.

9 Hedner T, Samuelsson O, Lunde H, Lindholm L, Andren L, Wibolm BE. Angio-oedema in relation to the treatment with angiotensin converting enzyme inhibitors. BMJ 1992; 304: 941-6.

10 Pigman EC, Scott JL. Angioedema in the emergency department: the impact of angiotensin-converting enzyme inhibitors. Am J Emerg Med 1993; 11: 3504.

11 Maier C. Life-threatening postoperative angioedema following treatment with an angiotensin converting enzyme inhibitor (German). Anaesthetist 1995; 44: 875-9.

12 O'Ryan F, Poor DB, Hattori M. Intraoperative angioedema induced by angiotensin-converting enzyme inhibitors: overview and case report. J Oral Maxillofac Surg 2005; 63: 551-6.

13 Ogbureke KU, Cruz C, Johnson JV, Helfrick JF. Perioperative angioedema in a patient on long-term angiotensin-converting enzyme (ACE)-inhibitor therapy. J Oral Maxillofac Surg 1996; 54: 917-20.

14 Jain M, Armstrong L, Hall J. Predisposition to and late onset of upper airway obstruction following angiotensin-converting enzyme inhibitor therapy. Chest 1992; 102: 871-4.

15 Schiller PI, Messmer SL, Haefeli WE, Schlienger RG, Bircher AJ. Angiotensin-converting enzyme induced angioedema: late onset, irregular course, and potential role of triggers. Allergy 1997; 52: 432-5.

16 Ulmer JL, Garvey MJ. Fatal angioedema associated with lisinopril. Ann Pharmacother 1992; 26: 1245-6.

17 Ducroix JP, Outurquin S, Benabes-Jezraoui B, et al. Angioedema and angiotensin converting enzyme inhibitors: a report of 19 cases (French). Rev Med Interne $2004 ; 25$ : 501-6.

18 Jason DR. Fatal angioedema associated with captopril. J Forensic Sci 1992; 37: 1418-21.

19 Oike Y, Ogata Y, Higashi D, Matsumura T, Numata $\Upsilon$. Fatal angioedema associated with enalapril. Intern 
Med 1993; 32: 308-10.

20 Dean DE, Schultz DL, Powers RH. Asphyxia due to angiotensin converting enzyme (ACE) inhibitor mediated angioedema of the tongue during the treatment of hypertensive heart disease. J Forensic Sci 2001; 46: 1239-43.

21 Messerli FH, Nussberger J. Vasopeptidase inhibition and angio-oedema. Lancet 2000; 356: 608-9.

22 Neutel JM. Effect of the renin-angiotensin system on the vessel wall: using ACE inhibition to improve endothelial function. J Hum Hypertens 2004; 18 : 599-606.

23 Anonymous. Effects of enalapril on mortality in severe congestive heart failure. Results of the Cooperative North Scandinavian Enalapril Survival Study (CONSENSUS). The CONSENSUS Trial Study Group. N Engl J Med 1987; 316: 1429-35.

24 Anonymous. Effect of enalapril on survival in patients with reduced left ventricular ejection fractions and congestive heart failure. The SOLVD Investigators. N Engl J Med 1991; 325: 293-302.

25 Cohn JN, Johnson G, Ziesche S, et al. A comparison of enalapril with hydralazine-isosorbide dinitrate in the treatment of chronic congestive heart failure. $\mathrm{N} \mathrm{Engl}$ J Med 1991; 325, 303-10.

26 Garg, R, Yusuf, S. Overview of randomized trials of angiotensin-converting enzyme inhibitors on mortality and morbidity in patients with heart failure. Collaborative Group on ACE Inhibitor Trials. JAMA 1995; 273: 1450-6.

27 Pfeffer MA. ACE inhibition in acute myocardial infarction. N Engl J Med 1995; 332: 118-20.

28 Elliott HL. Clinical use of angiotensin-converting enzyme inhibitors in patients with renal impairment . Blood Press Suppl 1994; 2: 31-4.

29 Bertrand ME. Provision of cardiovascular protection by ACE inhibitors: a review of recent trials. Curr Med Res Opin 2004; 20: 1559-69.

30 Yosuf S, Sleight P, Pogue J, Borsch J, Davies R, Dagenais $G$. Effects of an angiotensin-convertingenzyme inhibitor, ramipril, on cardiovascular events in high-risk patients. The Heart Outcomes Prevention Evaluation Study Investigators. N Engl J Med 2000; 342: 145-53.

31 Hunt S, Baker DW, Chin MH, et al. ACC/AHA guidelines for the evaluation and management of chronic heart failure in the adult: executive summary. A report of the American College of Cardiology/ American Heart Association Task Force on Practice Guidelines. J Am Coll Cardiol 2001; 38: 2101-13.

32 Anonymous. Failure to treat heart failure (Editorial). Lancet 1992; 339: 278-9.

33 Cleland JG, Khand A, Clark A. The heart failure epi- demic: exactly how big is it? Eur Heart J 2001; 22: 623-6.

34 Montanaro D, Gropuzzo M, Tulissi P, et al.

Renoprotective effect of early inhibition of the reninangiotensin system in renal transplant recipients. Transplant Proc 2005; 37: 991-3.

35 Bakris GL, Weir MR. Angiotensin-converting enzyme inhibitor-associated elevations in serum creatinine: is this a cause for concern? Arch Intern Med 2000; 160: 685-93.

36 Bouvy ML, Heerdink ER, Hoes AW, Lenfkens HG. Effects of NSAIDs on the incidence of hospitalisations for renal dysfunction in users of ACE inhibitors. Drug Saf 2003; 26: 983-9.

37 Cziraky MJ, Mehra IV, Wilson M, Bakris GL. Current issues in treating the hypertensive patient with diabetes: focus on diabetic nephropathy. Ann Pharmacother 1996; 30: 791-801.

38 Mogensen CE. Renoprotective role of ACE inhibitors in diabetic nephropathy. Br Heart J 1994; 72(3 Suppl): S38-45.

39 Rossing K, Jacobsen P, Pietraszek L, Parving HH. Renoprotective effects of adding angiotensin II receptor blocker to maximal recommended doses of ACE inhibitor in diabetic nephropathy: a randomized double-blind crossover trial. Diabetes Care 2003; 26: 2268-74.

40 Rossing K, Christensen PK, Hansen BV, Carstensen $B$, Parving $H H$. Optimal dose of candesartan for renoprotection in type 2 diabetic patients with nephropathy: a double-blind randomized cross-over study. Diabetes Care 2003; 26: 150-5.

41 Andersen S, Tarnow L, Rossing P, Hansen BV, Parving $H H$. Renoprotective effects of angiotensin II receptor blockade in type 1 diabetic patients with diabetic nephropathy. Kidney Int 2000; 57: 601-6.

42 Strippoli GF, Craig M, Deeks JJ, Schena FP, Craig JC. Effects of angiotensin converting enzyme inhibitors and angiotensin II receptor antagonists on mortality and renal outcomes in diabetic nephropathy: systemic review. BMJ 2004; 329: 828-38.

43 Anonymous. Effects of ramipril on cardiovascular and microvascular outcomes in people with diabetes mellitus: results of the HOPE study and MICRO-HOPE substudy. Heart Outcomes Prevention Evaluation Study Investigators. Lancet 2000; 355: 253-9.

44 ACE Inbibitors in Diabetic Nephropathy Trialist Group. Should all patients with type 1 diabetes mellitus and microalbuminuria receive angiotensin-converting enzyme inhibitors? A meta-analysis of individual patient data. Ann Intern Med 2001; 134: 370-9.

45 Brewster UC, Perazella MA. The renin-angiotensinaldosterone system and the kidney: effects on kidney 
disease. Am J Med 2004; 116: 263-72.

46 Maschio G, Alberti D, Janin G, et al. Effect of the angiotensin-converting-enzyme inhibitor benazepril on the progression of chronic renal insufficiency. The Angiotensin-Converting-Enzyme Inhibition in Progressive Renal Insufficiency Study Group. N Engl J Med 1996; 334: 939-45.

47 Anonymous. Randomised placebo-controlled trial of effect of ramipril on decline in glomerular filtration rate and risk of terminal renal failure in proteinuric, nondiabetic nephropathy. The GISEN Group. Lancet 1997; 349: 1857-63.

48 Scheen AJ. Renin-angiotensin system inhibition prevents type 2 diabetes mellitus. Part 1. A meta-analysis of randomised clinical trials. Diabetes Metab 2004; 30: 487-96.

49 Boblen L, de Courten M, Weidmann P. Comparative study of the effect of ACE inhibitors and other antihypertensive agents on proteinuria in diabetic patients. Am J Hypertens 1994; 7(9 Pt 2): 84S-92S.

50 Lewis EJ, Hunsicker LG, Bain RP, Robde RD. The effect of angiotensin-converting-enzyme inhibition on diabetic nephropathy. The Collaborative Study Group. N Engl J Med 1993; 329: 1456-62.

51 Brown NJ, Agirbasli MA, Williams GH, Litchfield WR, Vaughan DE. Effect of activation and inhibition of the renin-angiotensin system on plasma PAI-1. Hypertension 1998; 32: 965-71.

52 Furubashi M, Ura N, Higashiura $K$, et al. Blockade of the renin-angiotensin system increases adiponectin concentrations in patients with essential hypertension. Hypertension 2003; 42: 76-81.

53 Sharma $A M$. Is there a rationale for angiotensin blockade in the management of obesity hypertension? Hypertension 2004; 44: 12-9.

54 Arita Y, Kihara S, Ouchi N, et al. Paradoxical decrease of an adipose-specific protein, adiponectin, in obesity. Biochem Biophys Res Commun 1999; 257: 79-83.

55 Yamauchi T, Kamon J, Waki $H$, et al. The fat-derived hormone adiponectin reverses insulin resistance associated with both lipoatrophy and obesity. Nat Med 2001; 7: 941-6.

56 Okamoto $\Upsilon$, Kibara $S$, Ouchi N, et al. Adiponectin reduces atherosclerosis in apolipoprotein E-deficient mice. Circulation 2002; 106: 2767-70.

57 Reid IA. Vasoactive peptides. In: Katzung BG (Ed.). Basic and Clinical Pharmaclogy, $9^{\text {th }}$ ed. McGraw Hill; 2003.

58 Jensen NF, Weiler JM. Cl esterase inhibitor deficien$\mathrm{cy}$, airway compromise, and anesthesia. Anesth Analg 1998; 87: 480-8.

59 Rosen FS, Davis AE III. Deficiencies of Cl inhibitor.
Best Pract Res Clin Gastroenterol 2005; 19: 251-61.

60 Ishoo E, Shah UK, Grillone GA, Stram JR, Fuleihan

NS. Predicting airway risk in angioedema: staging system based on presentation. Otolaryngol Head Neck Surg 1999; 121: 263-8.

61 Hill MD, Lye T, Moss $H$, et al. Hemi-orolingual angioedema and ACE inhibition after alteplase treatment of stroke. Neurology 2003; 13: 1525-7.

62 Molinaro G, Gervais N, Adam A. Biochemical basis of angioedema associated with recombinant tissue plasminogen activator treatment: an in vitro experimental approach. Stroke 2002; 33: 1712-6.

63 Agostoni A, Cicardi M. Drug-induced angioedema without urticaria. Drug Saf 2001; 24: 599-606.

64 Israili $Z H$, Hall WD. Cough and angioneurotic edema associated with angiotensin-converting enzyme inhibitor therapy. A review of the literature and pathophysiology. Ann Intern Med 1992; 117 : 234-42.

65 Kostis JB, Packer M, Black HR, Schmieder R, Henry $D$, Levy E. Omapatrilat and enalapril in patients with hypertension: the Omapatrilat Cardiovascular Treatment vs. Enalapril (OCTAVE) trial. Am J Hypertens 2004; 17: 103-11.

66 Agah R, Bandi V, Guntupalli KK. Angioedema: the role of ACE inhibitors and factors associated with poor clinical outcome. Intensive Care Med 1997; 23: 793-6.

67 Bielory L, Lee SS, Holland CL, Jaker M. Long-acting ACE inhibitor-induced angioedema. Allergy Proc 1992; 13: 85-7.

68 Rees RS, Bergman J, Ramirez-Alexander R. Angioedema associated with lisinopril. Am J Emerg Med 1992; 10: 321-2.

69 Guo W, Turlapaty P, Shen $\Upsilon$, et al. Clinical experience with perindopril in patients non responsive to previous antihypertensive therapy: a large US community trial. Am J Ther 2004; 11: 199-205.

70 Schuster C, Reinhart WH, Hartmann K, Kubn M. Angioedema induced by ACE inhibitors and angiotensin II-receptor antagonists: analysis of 98 cases (German). Schweiz Med Wochenschr 1999; 129: 362-9.

71 Wernze H. ACE inhibitor-induced angioedema: remarkable new perspectives for intensive care/emergency medicine (German). Anasthesiol Intensivmed Notfallmed Schmerzther 1998; 33: 637-41.

72 Prisant LM. Angioneurotic edema. J Clin Hypertens (Greenwich) 2001; 3: 262-3.

73 Golden WE, Cleves MA, Heard JK, Brasher R, McKinney P, Jobnston JC. Frequency and recognition of angiotensin-converting enzyme inhibitor-associated angioneurotic edema. Clin Perform Qual Health 
Care 1993; 1: 205-7.

74 Agostoni A, Cicardi M, Cugno M, Zingale LC, Gioffre $D$, Nussberger J. Angioedema due to angiotensinconverting enzyme inhibitors. Immunopharmacology 1999; 44: 21-5.

75 Adams KF Jr. Pathophysiologic role of the reninangiotensin-aldosterone and sympathetic nervous systems in heart failure. Am J Health-Syst Pharm 2004; 61(Suppl 2): S4-13.

76 Razis PA, Coulson IH, Gould TR, Findley IL. Acquired $\mathrm{Cl}$ esterase inhibitor deficiency. Anaesthesia 1986; 41: 838-40.

77 Sabroe RA, Black $A K$. Angiotensin-converting enzyme (ACE) inhibitors and angio-oedema. $\mathrm{Br} \mathrm{J}$ Dermatol 1997, 136: 153-8.

78 Blais C Jr, Rouleau JL, Brown NJ, et al. Serum metabolism of bradykinin and des-Arg9-bradykinin in patients with angiotensin-converting enzyme inhibitor-associated angioedema. Immunopharmacology 1999; 43: 293-302.

79 Molinaro G, Cugno M, Perez $M$, et al. Angiotensinconverting enzyme inhibitor-associated angioedema is characterized by a slower degradation of desarginine(9)-bradykinin. J Pharmacol Exp Ther 2002; 303: 232-7.

80 Steinbach O, Schweder R, Freitag B. Cl-esterase inhibitor in ACE inhibitor-induced severe angioedema of the tongue (German). Anaesthesiol Reanim 2001; 26: 133-7.

81 Kleiner GI, Giclas P, Stadtmaner G, CunninghamRundles $C$. Unmasking of acquired autoimmune $\mathrm{Cl}$-inhibitor deficiency by an angiotensin-converting enzyme inhibitor. Ann Allergy Asthma Immunol 2001; 86: 461-4.

82 Bas M, Hoffmann TK, Bier H, Kojda G. Increased Creactive protein in ACE-inhibitor-induced angioedema. Br J Clin Pharmacol 2005; 59: 233-8.

83 Gibbs CR, Lip GY, Beevers DG. Angioedema due to ACE inhibitors: increased risk in patients of African origin. Br J Clin Pharmacol 1999; 48: 861-5.

84 Abbosh J, Anderson JA, Levine AB, Kupin WL. Angiotensin converting enzyme inhibitor-induced angioedema more prevalent in transplant patients. Ann Allergy Asthma Immunol 1999; 82: 473-6.

85 Morimoto T, Gandhi TK, Fiskio JM, et al. An evaluation of risk factors for adverse drug events associated with angiotensin-converting enzyme inhibitors. J Eval Clin Pract 2004; 10: 499-509.

86 Chin AG, Newkirk KA, Davidson BJ, Burningham $A R$, Krowiak EJ, Deeb ZE. Angiotensin-converting enzyme inhibitor-induced angioedema: a multicenter review and an algorithm for airway management. Ann Otol Rhinol Laryngol 2001; 110: 834-40.
87 Brown NJ, Snowden M, Griffin MR. Recurrent angiotensin-converting enzyme inhibitor-associated angioedema. JAMA 1997; 278: 232-3.

88 Marceau $F$. Is there a role for bradykinin in the therapeutic and side effects of angiotensin-converting enzyme inhibitors ? Can J Cardiol 1997, 13: 187-94.

89 Thompson T, Frable MA. Drug-induced, life threatening angioedema revisited. Laryngoscope 1993; 103(1 Pt 1): 10-2.

90 Bentsianov BL, Parbiscar A, Azer M, Har-El G. The role of fiberoptic nasopharyngoscopy in the management of the acute airway in angioneurotic edema. Laryngoscope 2000; 110: 2016-9.

91 Schmidt TD, McGrath KM. Angiotensin-converting enzyme inhibitor angioedema of the intestine: a case report and review of the literature. Am J Med Sci 2002; 324: 106-8.

92 Mullins RJ, Shanaban TM, Dobson RT. Visceral angioedema related to treatment with an ACE inhibitor. Med J Aust 1996; 165: 319-21.

93 Cohen EG, Soliman AM. Changing trends in angioedema. Ann Otol Rhinol Laryngol 2001; 110 : 701-6.

94 Cicardi M, Zingale LC, Bergamaschini L, Agostoni $A$. Angioedema associated with angiotensin-converting enzyme inhibitor use: outcome after switching to a different treatment. Arch Intern Med 2004; 164: 910-3.

95 Warrier MR, Copilevitz CA, Dykewicz MS, Slavin $R G$. Fresh frozen plasma in the treatment of resistant angiotensin converting enzyme inhibitor angioedema. Ann Allergy Asthma Immunol 2004; 92: 573-5.

96 Karim MY, Masood A. Fresh-frozen plasma as a treatment for life-threatening ACE-inhibitor angioedema. J Allergy Clin Immunol 2002; 109: 370-1.

97 Pylypchuk GB. ACE inhibitor- versus angiotensin II blocker-induced cough and angioedema. Ann Pharmacother 1998; 32: 1060-6.

98 Van Rijnsoever EW, Kwee-Zuiderwijk WJ, Feenstra J. Angioneurotic edema attributed to the use of losartan. Arch Intern Med 1998; 158: 2063-5.

99 Chin AG, Krowiak EJ, Deeb ZE. Angioedema associated with angiotensin II receptor antagonists: challenging our knowledge of angioedema and its etiology. Laryngoscope 2001; 111: 1729-31.

100 Howes LG, Tran D. Can angiotensin receptor antagonists be used safely in patients with previous ACE inhibitor-induced angioedema? Drug Saf 2002; 25: 73-6. 